\title{
Effect of energy renovation on indoor air quality in multifamily residential buildings in
} Slovakia

\author{
Földváry, Veronika ; Bekö, Gabriel; Langer, Sarka; Arrhenius, Karine ; Petráš, Dušan
}

Published in:

Building and Environment

Link to article, DOI:

10.1016/j.buildenv.2017.06.009

Publication date:

2017

Document Version

Peer reviewed version

Link back to DTU Orbit

Citation (APA):

Földváry, V., Bekö, G., Langer, S., Arrhenius, K., \& Petráš, D. (2017). Effect of energy renovation on indoor air quality in multifamily residential buildings in Slovakia. Building and Environment, 122, 363-372.

https://doi.org/10.1016/j.buildenv.2017.06.009

\section{General rights}

Copyright and moral rights for the publications made accessible in the public portal are retained by the authors and/or other copyright owners and it is a condition of accessing publications that users recognise and abide by the legal requirements associated with these rights.

- Users may download and print one copy of any publication from the public portal for the purpose of private study or research.

- You may not further distribute the material or use it for any profit-making activity or commercial gain

- You may freely distribute the URL identifying the publication in the public portal 


\title{
Effect of energy renovation on indoor air quality in multifamily residential buildings in Slovakia
}

\author{
Veronika Földváry ${ }^{1, *}$, Gabriel Bekö², Sarka Langer ${ }^{3,4}$, Karine Arrhenius ${ }^{5}$, Dušan Petráš ${ }^{1}$
}

${ }^{1}$ Faculty of Civil Engineering, Slovak University of Technology, Bratislava, Slovakia, Radlinského 11, 81005 Bratislava

${ }^{2}$ International Centre for Indoor Environment and Energy, Department of Civil Engineering, Technical University of Denmark, Nils Koppels Allé 402, 2800 Lyngby, Denmark

${ }^{3}$ IVL Swedish Environmental Research Institute, P.O. Box 530 21, 40014 Göteborg, Sweden

${ }^{4}$ Department of Civil and Environmental Engineering, Division of Building Services Engineering, Chalmers University of Technology, 41296 Göteborg, Sweden

${ }^{5}$ RISE Research Institutes of Sweden, Department of Chemistry, P.O. Box 857, 50115 Borås, Sweden ${ }^{*}$ Corresponding email: veronika.foldvary@gmail.com

Keywords: retrofitting, apartment buildings, natural ventilation, air exchange rate, occupant perception

\section{Abstract}

Buildings are responsible for a substantial portion of the global energy consumption. Most of the multifamily residential buildings built in the $20^{\text {th }}$ century in Central and Eastern Europe do not satisfy the current requirements on energy efficiency. Nationwide measures are taken to improve the energy efficiency of these buildings. The impact of these measures on the indoor air quality (IAQ) is rarely considered. The objective of the present study was to evaluate the impact of simple energy renovation on IAQ, air exchange rates (AERs) and occupant satisfaction in multifamily residential buildings in Slovakia. Three pairs of identical naturally ventilated multifamily residential buildings were examined. One building in each pair was newly renovated, the other was in its original condition. Temperature, relative humidity (RH) and the concentration of carbon dioxide $\left(\mathrm{CO}_{2}\right)$ were measured in 94 apartments $(57 \%)$ during one week in the winter. A questionnaire related to perceived air quality, sick building syndrome symptoms and airing habits was filled by the occupants. In a companion experiment, the IAQ was investigated in 20 apartments (50\%) 
1 of a single residential building before and after its renovation. In this experiment, concentrations of nitrogen

2 dioxide $\left(\mathrm{NO}_{2}\right)$, formaldehyde and total and individual volatile organic compounds (TVOC, VOC) were also

3 measured. $\mathrm{CO}_{2}$ concentrations were significantly higher and air exchange rates were lower in the renovated

4 buildings. Formaldehyde concentrations increased after renovation and were positively correlated with $\mathrm{CO}_{2}$

5 and RH. Building energy renovation was associated with lower occupant satisfaction with the indoor

6 climate. Simple energy retrofitting efforts should be complemented with improved ventilation in order to

7 avoid adverse effects on the quality of the indoor environment.

\section{$8 \quad 1$ Introduction}

9 Buildings are responsible for one third of the global energy consumption [1]. Reduction of energy 10 consumption and greenhouse gas emissions is a national priority in the European Union member countries

$11[1,2]$. The residential sector represents a major target group for national programs supporting energy

12 efficiency improvements of existing buildings. More than $50 \%$ of the European population resides in 13 multifamily buildings [3].

14 The potential negative impact of building energy conservation measures on indoor air quality is a matter of 15 concern. Minimizing air infiltration by tightening the building envelope is a common practice [4, 5, 6, 7, 8, 169 9. When unaccompanied by improved ventilation, such energy saving measures can lead to insufficient 17 ventilation rates [10] and increased exposure of building occupants to indoor pollutants [11, 12, 13].

18 Residential exposure is of particular concern, as more than half of the time spent indoors takes place in 19 residences [14]. It is therefore important to understand how energy saving strategies influence indoor air 20 quality and the comfort and health of occupants.

21 Studies on the impact of energy retrofits of dwellings on IAQ are relatively limited. Improved thermal

22 conditions and health indicators were reported after installing standard insulation in New Zealand [15]. In

23 California, comprehensive energy retrofits combined with improved mechanical ventilation systems and

24 air cleaners resulted in improved indoor environmental conditions [16]. Positive effects of energy 
1 retrofitting on indoor environmental quality and occupant satisfaction were also shown in mechanically

2 ventilated residential buildings in Sweden [17]. Additionally, better indoor air quality in low-energy or

3 passive houses compared to conventionally built houses has been reported in a number of studies [18, 19,

4 20, 21]. Satisfactory indoor air quality in these buildings was achieved by relatively high air exchange rates

5 provided by mechanical ventilation.

6 Energy saving measures started to receive increased attention in Central and Eastern Europe since the

7 1990’s, two decades later than in Western Europe. Indoor air quality however does not receive consideration

8 to the same extent. Adoption of new building standards with primary focus on energy conservation is feared

9 to compromise indoor air quality. This is especially the case in the almost exclusively naturally ventilated

10 buildings built before 1990. Very few studies have been conducted in multifamily residential buildings in

11 Central and Eastern Europe [21, 22, 23, 24]. Multifamily residential buildings in Slovakia were built

12 between 1948 and 1990 and they well represent the residential building stock of Central and Eastern Europe.

13 About $70 \%$ of these buildings do not fulfil the current European requirements for energy efficiency [25].

14 This has led to the implementation of numerous energy retrofit campaigns for existing multifamily

15 buildings [3]. However, the effect of these programs on indoor air quality and occupant wellbeing is

16 neglected.

17 The objectives of the present study were to evaluate in multifamily residential buildings in Slovakia the

18 impact of energy renovation on i) temperature, relative humidity, $\mathrm{CO}_{2}$ concentration, air exchange rates and

19 concentrations of selected air pollutants using objective measurements, and on ii) perceived air quality and

20 occupants' airing habits using questionnaire survey.

\section{$21 \quad 2$ Materials and methods}

\section{$22 \quad 2.1$ Experiment I}

$23 \quad$ 2.1.1 Selected buildings

24 The first experiment included three pairs of multi-storey residential buildings made of prefabricated and 25 pre-stressed concrete panels. Each pair consisted of a non-renovated and an identical renovated building 
1 (Table 1). The energy-retrofitting measures included thermal insulation of the façade and the roof, and

2 hydraulic balancing of the continuously operating heating system. The façade was insulated with expanded

3 foam polystyrene of $80 \mathrm{~mm}$ thickness. Mineral wool insulation of $120 \mathrm{~mm}$ thickness was added to the roof.

4 The ground floor apartments in each building were situated above an unheated basement. The basement

5 ceiling was thermally insulated with $80 \mathrm{~mm}$ thick expanded foam polystyrene. No changes have been made

6 to the windows, since new plastic frame windows have been already installed by the owners in most of the

7 apartments before the study. All buildings were naturally ventilated. Exhaust fans operated by the light

8 switch were present in the bathrooms and toilets. No modifications were made to the ventilation systems

9 during the renovation. All buildings were located within $1 \mathrm{~km}$ from each other, in the rural city of Šamorín

10 (13.000 inhabitants), $25 \mathrm{~km}$ from the capital of Slovakia, Bratislava.

11 Table 1. Characteristics of the studied buildings

\begin{tabular}{|c|c|c|c|c|c|c|}
\hline Building pair & \multicolumn{2}{|c|}{ I. } & \multicolumn{2}{|c|}{ II. } & \multicolumn{2}{|c|}{ III. } \\
\hline Building condition & Original & Renovated & Original & Renovated & Original & Renovated \\
\hline Construction year & 1965 & 1970 & 1970 & 1972 & 1980 & 1983 \\
\hline Major orientation & East & East & Northwest & Northwest & North & North \\
\hline Height (m) & 27.7 & 27.7 & 30.2 & 30.2 & 13.1 & 13.1 \\
\hline Number of floors & 10 & 10 & 9 & 9 & 4 & 4 \\
\hline $\begin{array}{l}\text { Number of apartments } \\
\text { on each floor }\end{array}$ & 4 & 4 & 2 & 2 & 6 & 6 \\
\hline $\begin{array}{l}\text { Number of measured } \\
\text { apartments }\end{array}$ & 20 & 20 & 11 & 15 & 14 & 14 \\
\hline $\begin{array}{l}\text { Volume of each } \\
\text { apartment }\left(\mathrm{m}^{3}\right)\end{array}$ & 210 & 210 & 258 & 258 & 194 & 194 \\
\hline $\begin{array}{l}\text { Area of each apartment } \\
\left(\mathrm{m}^{2}\right)\end{array}$ & 75 & 75 & 92 & 92 & 69 & 69 \\
\hline $\begin{array}{l}\text { Heating system/Heating } \\
\text { device }\end{array}$ & & Dis & $\mathrm{ng} / \mathrm{Rad}$ & therm & ves & \\
\hline
\end{tabular}

12

\subsubsection{Physical measurements and questionnaire survey}

14 The experiment was carried out between the middle of November 2013 and the end of January 2014.

15 Ninety-four apartments were investigated in total, 45 were in the three non-renovated and 49 in the three

16 renovated buildings. The measurements in each apartment lasted one week.

17 Air temperature and relative humidity were measured in the bedrooms by HOBO U12-012 data loggers

18 (Onset Computer Corp., USA). The concentrations of $\mathrm{CO}_{2}$ were measured with 5-minute intervals by

19 CARBOCAP $\mathrm{CO}_{2}$ monitors (GMW22, Vaisala, Finland) connected to the HOBO data logger. All 
1 instruments were newly calibrated prior to the measurements. The locations of the instruments were

2 selected with respect to the limitations of the $\mathrm{CO}_{2}$ method [26]. Each unit was placed at a sufficient distance

3 from windows and beds to minimize the influence of the incoming fresh air or the influence of sleeping

4 occupants.

$5 \quad \mathrm{CO}_{2}$ concentrations obtained between 20:30 and 6:30 during each measured night, room volume and the 6 occupants' body weight and height were used to calculate the AER in the bedrooms. The methodology

7 using a spreadsheet that employed the carbon dioxide mass balance equation has been described in detail

8 earlier [27]. Briefly, the $\mathrm{CO}_{2}$ concentration build-up period was used to estimate the AER for each

9 respective night in the occupants' bedrooms [26, 27, 28, 29]. Air exchange rate in the room was estimated

10 by fitting a non-linear curve to the measured pattern of the $\mathrm{CO}_{2}$ concentration at a given $\mathrm{CO}_{2}$ emission rate,

11 room volume and outdoor $\mathrm{CO}_{2}$ concentration. Occasionally $\mathrm{CO}_{2}$ concentration decays were used, when

$12 \mathrm{CO}_{2}$ levels began to fall while the room was occupied in the evening, i.e. when the occupants indicated that

13 they aired out. When the concentration build-up or decay could not be clearly defined, the air exchange rate

14 was determined using a mass balance model applied on the estimated steady-state $\mathrm{CO}_{2}$ concentration [26].

15 Only trustworthy fractions of the night periods with clear $\mathrm{CO}_{2}$ concentration patterns were extracted and 16 used for further analysis. AERs were determined separately for each night with known occupancy. The

17 final air exchange rate for each bedroom was calculated as a time-weighted average of the air exchange

18 rates obtained for each relevant time period.

19 One occupant in each apartment was asked to fill a questionnaire. The questions were related to some 20 building characteristics, occupant behavior and habits (e.g. frequency and duration of airing), sick building

21 syndrome symptoms and occupants' perception of the indoor air quality and thermal environment (e.g.

22 acceptability of indoor air quality in the apartments using the continuous acceptability scale [3034]. The

23 questionnaire used in the renovated buildings contained additional questions related to potential changes in

24 the occupants' indoor climate related behavior after renovation (e.g. self-reported altered airing habits).

\section{$25 \quad 2.2$ Experiment II}


2 The second experiment was performed in the original building of building pair I from Table 1. After a new

3 set of winter measurements in 20 apartments (50\%), the building was renovated in the fashion described in

4 section 2.1.1. The measurements were then repeated in the same apartments during the following winter.

5 The 20 apartments were equally distributed on the lower, middle and higher floors of the building. No major

6 changes were made to the interior of the apartments between the two measurement campaigns, unless stated

7 otherwise (replaced furniture or carpet in three apartments; see section “3.3 Impact of renovation on $\mathrm{NO}_{2}$,

8 VOCs and formaldehyde”.

\subsubsection{Physical measurements and questionnaire survey}

11 The week-long measurements in the second experiment were carried out simultaneously in all 20

12 apartments. The first round of measurements (non-renovated condition) was performed in January 2015. In

13 order to have as similar outdoor conditions as possible during the two measurement campaigns, the follow-

14 up measurements (renovated condition) were performed in January 2016.

15 Temperature, relative humidity and $\mathrm{CO}_{2}$ concentrations were measured and AERs were calculated using 16 the same methodology as in Experiment I (section 2.1.2). A set of passive samplers for $\mathrm{NO}_{2}$, formaldehyde 17 and VOCs were placed centrally in the living room of each investigated apartment (Figure S1) [18, 31].

18 The samplers were placed at least $1.5 \mathrm{~m}$ above the floor. Locations near windows and radiators were 19 avoided. $\mathrm{NO}_{2}$ was measured with IVL diffusive samplers [32]. This technique provides an average

20 concentration of the target pollutants in the air during the measured time period. The samplers were 21 analysed for $\mathrm{NO}_{2}$ with a wet chemical technique using a spectrophotometric method. The analytical 22 procedure is accredited by the Swedish accreditation agency SWEDAC. The measurement uncertainty was $2310 \%$ at $95 \%$ confidence level. The limit of detection (LOD) was $0.5 \mu \mathrm{g} / \mathrm{m}^{3}$. For outdoor measurement, one $24 \mathrm{NO}_{2}$ sampler was placed on a balcony on the third floor of the building. 
1 Formaldehyde was measured with DSD-DNPH UmeX-100 passive samplers (SKC Inc., Eighty Four, PA,

2 USA). The sampling period and the analytical technique (solvent extraction and high performance liquid

3 chromatography) followed the ISO $16000-4$ standard [33]. The LOD was $0.03 \mu \mathrm{g} / \mathrm{m}^{3}$. Adsorption tubes

4 filled with $200 \mathrm{mg}$ Tenax TA (Perkin-Elmer) were used for passive sampling of VOCs. Their analyses were

5 carried out in compliance with ISO 16017-2 [34]. The desorption of the tubes was carried out on a Markes

6 TD100 desorber, where the adsorbed substances were released by heating the sorbent tubes during 7 min

7 at $275^{\circ} \mathrm{C}$ and then transferred to a cold trap for focusing. The trap was then rapidly heated up again, analytes

8 were released and reached a gas chromatography (GC) column for separation. The column effluent was

9 split into two streams for the detection of individual compounds, one stream passing through the flame

10 ionization detector and the other stream through the mass spectrometer.

11 VOCs were analyzed on a gas chromatograph (Agilent technologies 6890N) equipped with a flame

12 ionization detector and a mass spectrometer 5975C inert MSD in the so-called electron impact mode. The

13 GC column was a non-polar capillary column (5\% phenyl polysilphenylene-siloxane, BPX5, 50 m long,

$140.32 \mathrm{~mm}$ internal diameter, $1 \mu \mathrm{m}$ film thickness). The temperature was held at $60^{\circ} \mathrm{C}$ for 2 minutes, then

15 increased to $100{ }^{\circ} \mathrm{C}$ at $4{ }^{\circ} \mathrm{C} / \mathrm{min}$, then increased to $280{ }^{\circ} \mathrm{C}$ at $6{ }^{\circ} \mathrm{C} / \mathrm{min}$, with hold time 15 minutes.

16 Calibration was done by application of microliter amounts of solution of toluene in diethyl ether on the

17 tubes. The concentration of TVOC and the the individual VOCs were quantified in toluene equivalents.

18 The limit of detection for the individual VOCs was $0.2 \mu \mathrm{g} / \mathrm{m}^{3}$ based on 3 times the signal-to-noise ratio.

19 All values below LOD were replaced with $1 \frac{1}{2}$ LOD.

20 The questionnaire survey was carried out concurrently with the physical measurements before and after the

21 renovation of the building, as described for Experiment I. 


\section{3. Results and discussion}

\subsection{Impact of renovation on temperature and relative humidity}

16 Table 2 presents the descriptive statistics of the measured parameters. The indoor air temperature was 17 significantly lower in the original buildings than in the renovated ones in both experiments ( $<<0.01)$ (Figure 18 1). The relative humidity was similar in the renovated and the non-renovated buildings.

19 In Experiment I, the average temperature in $18 \%$ of the apartments in the non-renovated buildings did not 20 fulfil the recommended optimal range $\left(20-24{ }^{\circ} \mathrm{C}\right)$ [35]. After renovation, only one apartment was under21 heated. However, energy renovation can lead to increased periods of overheating [36]. Overheating 22 occurred in three apartments (7\%) in the non-renovated buildings and in six apartments (12\%) in the 23 renovated ones. In both the renovated and the non-renovated buildings, the average relative humidity 24 slightly exceeded the recommended $60 \%$ in two of the apartments. 
1 In Experiment II, 25\% of the apartments before renovation had the average indoor temperature below 20

$2 \quad{ }^{\circ} \mathrm{C}$. No under-heating or overheating occurred after renovation. The average relative humidity slightly 3 exceeded the recommended $60 \%$ in only one apartment before renovation.
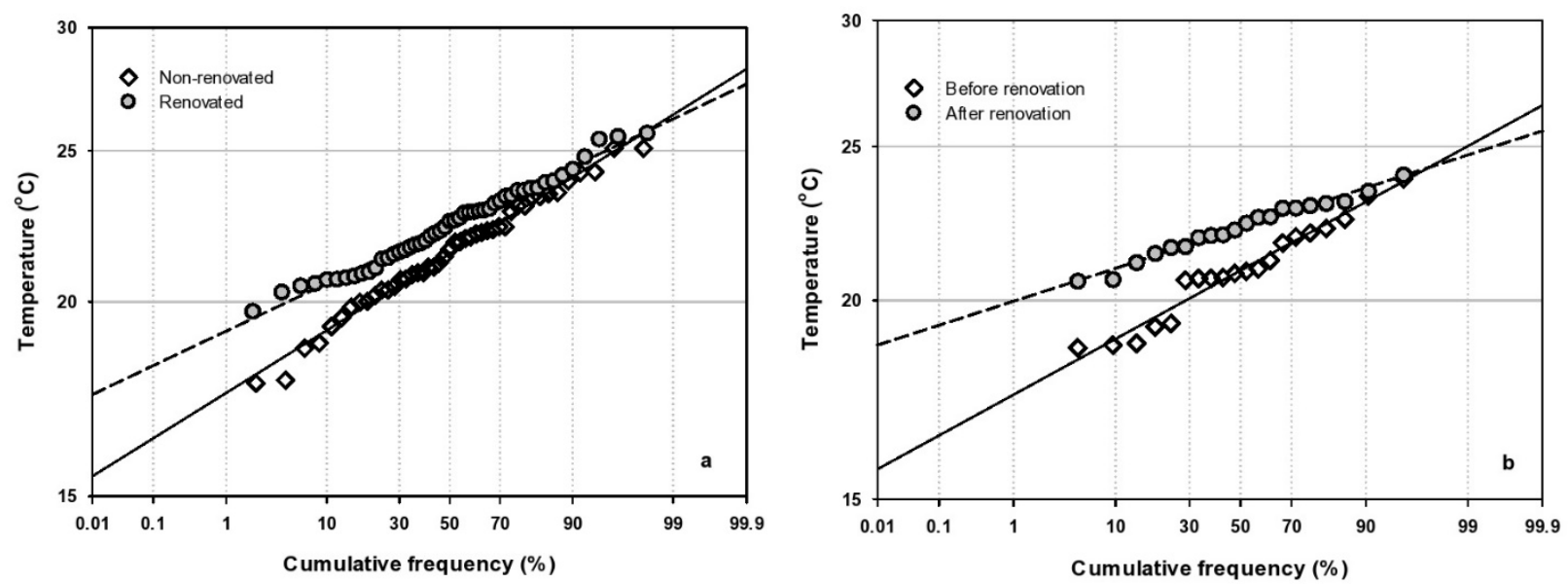

5 Figure 1. Cumulative frequency distribution of the average indoor temperatures in Experiment I (a) and 6 Experiment II (b).

7 Kotol et al. [37] reported under-heating in 17\% of the investigated Greenlandic households built in the 8 second half of the $20^{\text {th }}$ century. Temperatures lower than $20^{\circ} \mathrm{C}$ were found in $30-40 \%$ of Estonian [38] and 9 Lithuanian [22] dwellings. It has been suggested that the occupants may maintain low temperatures in order to minimize heating costs [39]. However, uninsulated dwellings built in the $20^{\text {th }}$ century may have

11 significantly lower indoor operative temperatures during the winter due to colder internal surfaces. 12 Howden-Chapman et al. [15], Liu et al. [40] and Pustayova [41] found that adding thermal insulation in 13 older dwellings increases the indoor air temperature in winter, which has positive implications for thermal 14 comfort and energy savings. In a Swedish study the indoor temperature ranged between $21-25{ }^{\circ} \mathrm{C}$ in the 15 retrofitted dwellings and between $19.7-21.8^{\circ} \mathrm{C}$ in the non-retrofitted ones [40]. In an earlier Slovak study 16 [41], the average indoor temperature in non-renovated multifamily buildings was lower $\left(18.3-23.6^{\circ} \mathrm{C}\right)$ than 17 in renovated ones $\left(22.2-25.3^{\circ} \mathrm{C}\right)$. In New Zealand households [15] the indoor temperature increased by 0.6 $18{ }^{\circ} \mathrm{C}$ and the relative humidity decreased by $1.4-3.8 \%$ after adding insulation on building envelope. 
1 
1 Table 2. Descriptive statistics of the measured parameters. Values are based on average values obtained for each apartment over the monitoring

2 period.

\begin{tabular}{|c|c|c|c|c|c|c|c|c|c|c|}
\hline & & & $\mathrm{T}\left({ }^{\circ} \mathrm{C}\right)$ & RH (\%) & $\begin{array}{c}\mathrm{CO}_{2} \text { whole } \\
\text { period (ppm) }\end{array}$ & $\begin{array}{c}\mathrm{CO}_{2} \text { night-time } \\
(\mathrm{ppm})\end{array}$ & $\operatorname{AER}\left(h^{-1}\right)^{c)}$ & $\mathrm{NO}_{2}\left(\mu \mathrm{g} / \mathrm{m}^{3}\right)$ & $\operatorname{TVOC}\left(\mu \mathrm{g} / \mathrm{m}^{3}\right)$ & $\begin{array}{c}\text { Formaldehyde } \\
\left(\mu \mathrm{g} / \mathrm{m}^{3}\right)\end{array}$ \\
\hline \multirow{8}{*}{ Experiment I a) } & \multirow{4}{*}{$\begin{array}{c}\text { Non- } \\
\text { renovated } \\
(\mathrm{N}=45)\end{array}$} & $\begin{array}{l}\text { Mean } \\
\text { (Min.-Max.) }\end{array}$ & $\begin{array}{c}21.5 \\
(17.6-25.1) \\
\end{array}$ & $\begin{array}{c}46 \\
(34-65) \\
\end{array}$ & $\begin{array}{c}1180 \\
(430-3380) \\
\end{array}$ & $\begin{array}{c}1425 \\
(480-3380) \\
\end{array}$ & $\begin{array}{c}0.79 \\
(0.22-3.69) \\
\end{array}$ & - & - & - \\
\hline & & Geom. Mean & 21.5 & 47 & 1100 & 1260 & 0.64 & - & - & - \\
\hline & & Median & 21.7 & 48 & 1100 & 1360 & 0.66 & - & - & - \\
\hline & & Std. Dev. & 1.8 & 7 & 495 & 675 & 0.69 & - & - & - \\
\hline & \multirow{4}{*}{$\begin{array}{l}\text { Renovated } \\
(\mathrm{N}=49)\end{array}$} & $\begin{array}{l}\text { Mean } \\
\text { (Min.-Max.) }\end{array}$ & $\begin{array}{c}22.5 \\
(19.2-25.8) \\
\end{array}$ & $\begin{array}{c}46 \\
(31-61)\end{array}$ & $\begin{array}{c}1380 \\
(510-3570)\end{array}$ & $\begin{array}{c}1680 \\
(630-3570) \\
\end{array}$ & $\begin{array}{c}0.48 \\
(0.06-1.33) \\
\end{array}$ & - & - & - \\
\hline & & Geom. Mean & 22.4 & 45 & 1295 & 1530 & 0.38 & - & - & - \\
\hline & & Median & 22.5 & 46 & 1290 & 1510 & 0.43 & - & - & - \\
\hline & & Std. Dev. & 1.5 & 1.3 & 590 & 745 & 0.31 & - & - & - \\
\hline \multirow{8}{*}{ Experiment II b) } & \multirow{4}{*}{$\begin{array}{c}\text { Before } \\
\text { renovation } \\
(\mathrm{N}=20)\end{array}$} & $\begin{array}{l}\text { Mean } \\
\text { (Min.-Max.) }\end{array}$ & $\begin{array}{c}20.9 \\
(18.7-23.9) \\
\end{array}$ & $\begin{array}{c}46 \\
(34-61) \\
\end{array}$ & $\begin{array}{c}1205 \\
(595-2665) \\
\end{array}$ & $\begin{array}{c}1410 \\
(595-1550) \\
\end{array}$ & $\begin{array}{c}0.61 \\
(0.32-1.15) \\
\end{array}$ & $\begin{array}{c}15.4 \\
(6.1-42.1) \\
\end{array}$ & $\begin{array}{c}569 \\
(179-1805) \\
\end{array}$ & $\begin{array}{c}32 \\
(15-54) \\
\end{array}$ \\
\hline & & Geom. Mean & 20.8 & 46 & 1165 & 1325 & 0.58 & 13.4 & 489 & 30 \\
\hline & & Median & 20.8 & 45 & 1190 & 1300 & 0.59 & 13.5 & 500 & 30 \\
\hline & & Std. Dev. & 1.5 & 8 & 400 & 515 & 0.2 & 8.9 & 357 & 9.4 \\
\hline & \multirow{4}{*}{$\begin{array}{c}\text { After } \\
\text { renovation } \\
(\mathrm{N}=20)\end{array}$} & $\begin{array}{l}\text { Mean } \\
\text { (Min.-Max.) }\end{array}$ & $\begin{array}{c}22.2 \\
(20.6-24.0) \\
\end{array}$ & $\begin{array}{c}48 \\
(39-59) \\
\end{array}$ & $\begin{array}{c}1570 \\
(790-3575) \\
\end{array}$ & $\begin{array}{c}1925 \\
(865-3575) \\
\end{array}$ & $\begin{array}{c}0.44 \\
(0.21-0.76) \\
\end{array}$ & $\begin{array}{c}16.5 \\
(4.5-36.2) \\
\end{array}$ & $\begin{array}{c}773 \\
(185-2362) \\
\end{array}$ & $\begin{array}{c}43 \\
(23-67) \\
\end{array}$ \\
\hline & & Geom. Mean & 22.2 & 48 & 1545 & 1825 & 0.42 & 14.5 & 623 & 41 \\
\hline & & Median & 22.3 & 48 & 1510 & 1870 & 0.45 & 16.3 & 575 & 42 \\
\hline & & Std. Dev. & 0.9 & 6 & 500 & 660 & 0.13 & 8.3 & 568 & 13 \\
\hline
\end{tabular}

3 a) Three pairs of residential buildings; one in each pair was in its original condition and the other was renovated.

4 b) Single residential building investigated before and after its renovation.

5 c) In Experiment $I, n=43$ in the non-renovated buildings and $n=44$ in the renovated building, due to missing data.

6 


\section{1}

2

3

4

5

6

7

8

\subsection{Impact of renovation on $\mathrm{CO}_{2}$ concentrations and air exchange rates}

In Experiment I, the median of the average $\mathrm{CO}_{2}$ concentrations obtained for each apartment for the whole measurement period was higher in the renovated than in the non-renovated buildings (1290 ppm vs. 1100 ppm; $\mathrm{p}>0.05$ ). Similar trend was observed for the $\mathrm{CO}_{2}$ concentrations in the night-time, when the occupants were presumably in the bedroom. The cumulative frequency distribution of the average night-time $\mathrm{CO}_{2}$ concentrations is shown in Figure 2. In the non-renovated buildings, the median night-time $\mathrm{CO}_{2}$ concentration was $1360 \mathrm{ppm}$, in the renovated dwellings it was $1510 \mathrm{ppm}$. On average, the $\mathrm{CO}_{2}$ concentration was above $1000 \mathrm{ppm}$ during 58\% of the measured night periods in the non-renovated buildings and during $72 \%$ in the renovated buildings. The highest 20-min running average of $\mathrm{CO}_{2}$ concentrations exceeded 1000 ppm, 2000 ppm and even 3000 ppm in a number of apartments; this was more frequent in the renovated buildings (Table S1).

The stepwise multivariate regression analysis (Figure S2, Table S2) confirmed the association between elevated $\mathrm{CO}_{2}$ concentrations and building renovation. Additional variables retained in the model were occupancy in the apartment and in the bedrooms (positive association) and the occupants' smoking habits (negative association). Lower $\mathrm{CO}_{2}$ concentrations in the smokers' apartments were presumably caused by different airing habits. Sixty percent of smokers indicated that they air out over a longer period (20-30 minutes on average), while $63 \%$ of non-smokers aired out on average for 7.5 minutes or less. The $\mathrm{CO}_{2}$ concentrations were higher in the renovated apartments despite the fact that more smokers lived in the renovated buildings (38\%) than in the non-renovated buildings (27\%).

The regression model explained $29 \%$ of the variation in the $\mathrm{CO}_{2}$ concentration. A stronger model could be obtained by including additional parameters, such as indoor-outdoor temperature difference, wind conditions and variables related to building characteristics and occupant behavior [10, 42]. Especially predictor variables related to occupant behavior are suspected to be of importance, as the climate and building related variables were similar for all investigated apartments. 
1 In Experiment II, the median of the average $\mathrm{CO}_{2}$ concentrations obtained for each apartment for the whole

2 measurement period was higher after renovation than before (1510 vs. 1190 ppm). The difference was

3 statistically significant $(\mathrm{p}<0.05)$. The median night-time $\mathrm{CO}_{2}$ concentration before renovation was 1300

4 ppm, while after renovation it was $1870 \mathrm{ppm}(\mathrm{p}<0.05)$. The average time fraction when the night-time $\mathrm{CO}_{2}$

5 concentration exceeded 1000 ppm was $69 \%$ before renovation and $80 \%$ after renovation. The average night-

6 time $\mathrm{CO}_{2}$ concentration increased with renovation in every apartment (by 3-360\%). According to the

7 questionnaire, the usual bedroom occupancy did not change between the two measurement campaigns,

8 which were a year apart.
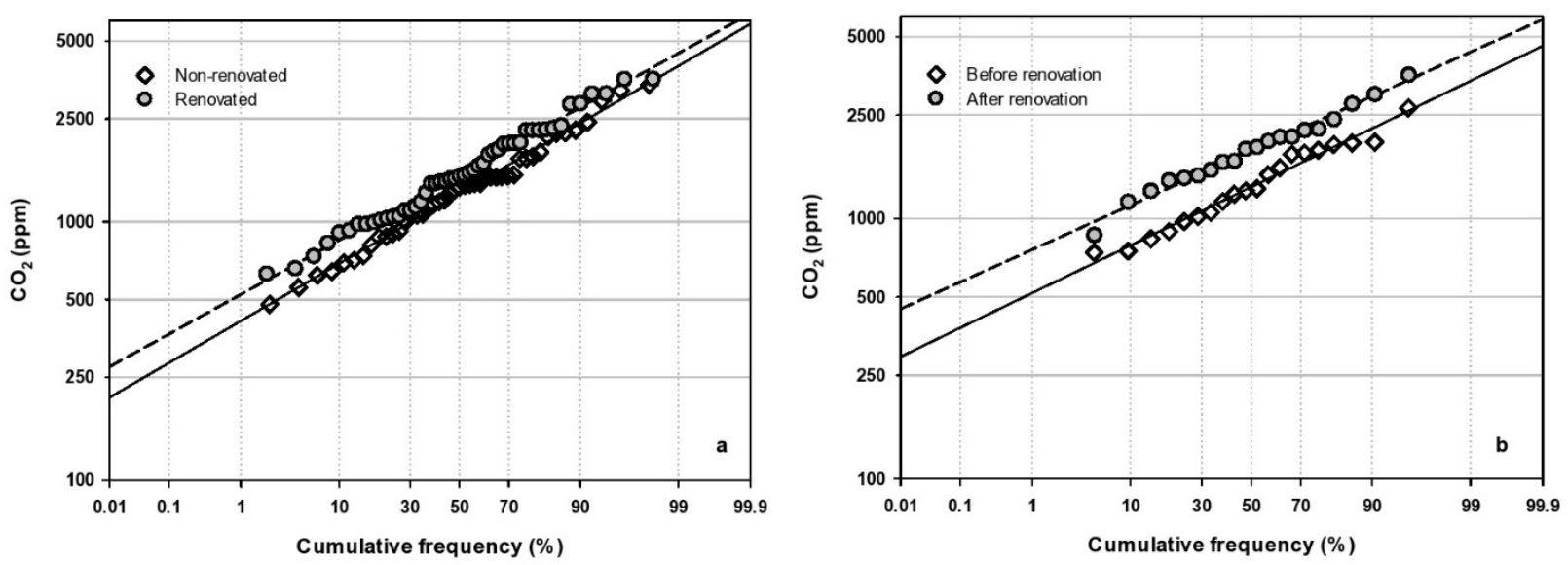

9

10

11

12

Figure 2. Cumulative frequency distribution of the average night-time $\mathrm{CO}_{2}$ concentrations in Experiment I (a) and Experiment II (b).

The air exchange rates were significantly lower in the renovated buildings than in the non-renovated ones in both Experiments $(\mathrm{p}<0.05)$. The median air exchange rates in both experiments were above the recommended minimum of $0.5 \mathrm{~h}^{-1}$ before renovation (Table 2). After renovation they decreased below this value. Figure 3 shows the cumulative frequency distribution of air exchange rates. In Experiment I, 37\% of the apartments in the non-renovated buildings and 58\% in the renovated buildings had an average air exchange rate below $0.5 \mathrm{~h}^{-1}$. In Experiment II, the air average exchange rate was below $0.5 \mathrm{~h}^{-1}$ in $40 \%$ of the apartments before renovation and in $85 \%$ after renovation. In 19 out of the 20 apartments the average air exchange rates decreased with renovation to 5-75\% of their corresponding value from a year earlier. 
1 New and renovated buildings are tighter than older buildings due to improved construction techniques and

2 stricter regulations. In our study, air exchange rates decreased despite the fact that windows were not

3 replaced during the renovation process. This indicates that adding insulation on the building envelope can

4 substantially increase air tightness and decrease infiltration, presumably through decreased air leakage area

5 (e.g. cracks, seals and joints between concrete panels, joints between walls and windows, other building

6 components). Without the implementation of ventilation systems, air exchange rates in such naturally

7 ventilated buildings can be low [27, 31, 42, 43, 44].

8 Du et al. [22] compared the indoor environmental quality in 40-year old non-renovated multifamily

9 buildings in Lithuania and Finland. Mechanical ventilation was present in $80 \%$ of the Finnish apartments,

10 in none of the Lithuanian ones. Significantly higher concentrations of $\mathrm{CO}_{2}$ and a number of air pollutants

11 were measured in the Lithuanian apartments. The authors concluded that the differences might also be

12 partly attributable to different occupant behaviour in the two countries. Although occupant behaviour can

13 change with building renovation (see section "3.4 Airing habits and perceived air quality"), it is unlikely

14 to fully explain the lower AER in the renovated buildings in our study, especially in Experiment II, where

15 the same apartments with the same occupants were investigated both before and after renovation.

16 With the increase in energy prices in the 1970s in Western and Northern Europe, ventilation rates decreased

17 until new building codes in the 1980s started to require higher ventilation rates [10, 27, 31]. In Central and

18 Eastern Europe energy prices increased in the 1990s. As minimum ventilation recommendations continue

19 to be rarely addressed in energy renovation programs, decreased air exchange rates in renovated buildings

20 may lead to increased exposure of occupants to indoor generated air pollutants. 

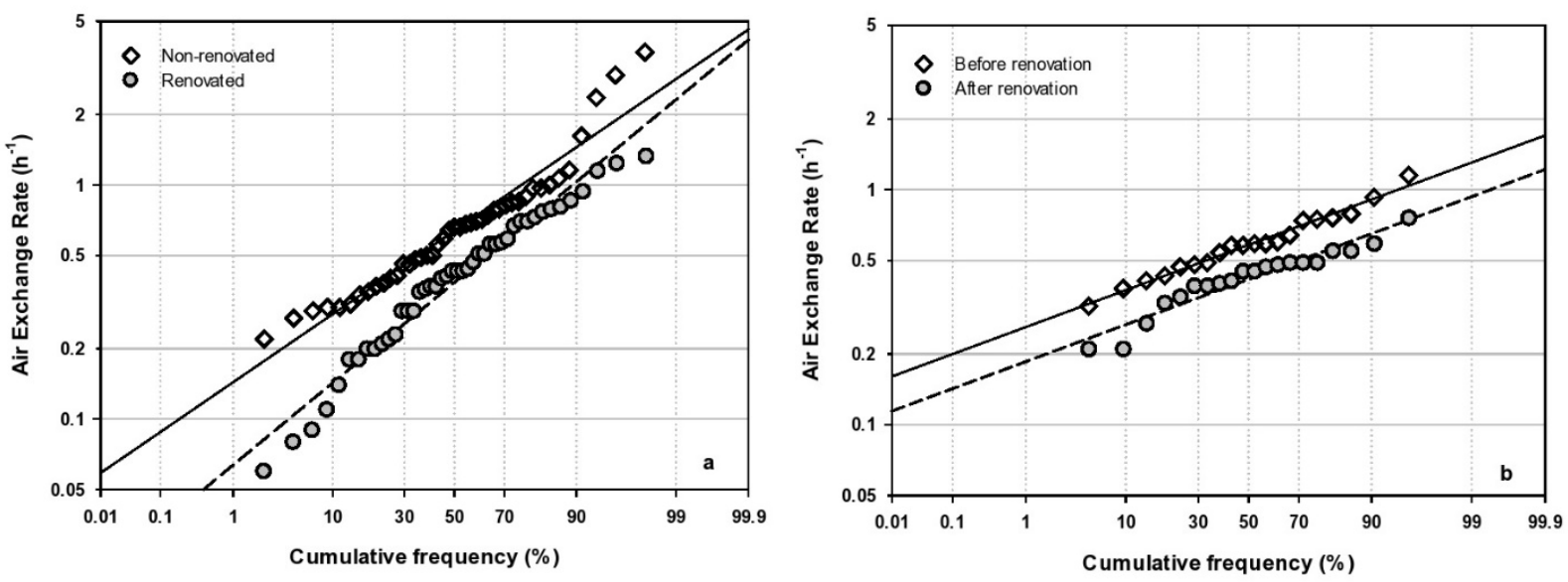

1

Figure 3. Cumulative frequency distribution of the average air exchange rates in Experiment I (a) and Experiment II (b).

\subsection{Impact of renovation on $\mathrm{NO}_{2}$, VOCs and formaldehyde}

The median concentration of $\mathrm{NO}_{2}$ across all apartments in Experiment II was lower than the recommended annual maximum of $40 \mu \mathrm{g} / \mathrm{m}^{3}$ [45], both before and after renovation. The recommended limit value was exceeded in one apartment before renovation. Lower median $\mathrm{NO}_{2}$ concentration was observed before renovation $\left(15.4 \mu \mathrm{g} / \mathrm{m}^{3}\right)$ than after renovation $\left(16.5 \mu \mathrm{g} / \mathrm{m}^{3}\right)$ (Figure 4a, Figure S3). The difference was not statistically significant ( $>>0.1$ ). The observed concentrations were similar to those reported in Northern Europe [30] and Lithuania [22]. Higher $\mathrm{NO}_{2}$ concentrations were observed in Czech Republic (37.7 $\left.\mu \mathrm{g} / \mathrm{m}^{3}\right)$ and Switzerland $\left(23.8 \mu \mathrm{g} / \mathrm{m}^{3}\right)[46]$.

In the absence of indoor combustion sources, the major source of $\mathrm{NO}_{2}$ indoors is outdoor air. The outdoor concentration of $\mathrm{NO}_{2}$ was $12.4 \mu \mathrm{g} / \mathrm{m}^{3}$ and $12.0 \mu \mathrm{g} / \mathrm{m}^{3}$ during the measurements before and after renovation, respectively. The indoor-to-outdoor $(\mathrm{I} / \mathrm{O})$ concentration ratios indicated the presence of indoor combustion sources in a number of apartments (Figure S4). The weak negative correlation between AER and $\mathrm{NO}_{2}$ (Table 3) further supports the presence of indoor sources. None of the apartments had a gas stove or a gas burner. Candle burning and smoking may have been responsible for the high I/O ratios. Smokers lived in $40 \%$ of the apartments. We did not collect detailed information on the frequency of candle burning and on 
1 the location, where smoking occurred. In order to better understand the impact of energy renovation on

2 indoor $\mathrm{NO}_{2}$ concentrations, continuous measurements, a longer measurement period and better

3 identification of the indoor sources of $\mathrm{NO}_{2}$ are warranted.

4 Table 3. Pearson correlation coefficients between the measured parameters (both measurement campaigns 5 combined, $\mathrm{N}=40$ ).

\begin{tabular}{|l|c|c|c|c|c|c|c|}
\hline Parameter & $\mathbf{N O}_{2}$ & Formaldehyde & TVOC & $\mathbf{C O}_{2}$ & $\mathbf{T}$ & $\mathbf{R H}$ & AER \\
\hline Formaldehyde & -0.09 & - & - & - & - & - & - \\
\hline TVOC & -0.09 & 0.27 & - & - & - & - & - \\
\hline $\mathbf{C O}_{2}$ & 0.2 & $0.57^{*}$ & 0.16 & - & - & - & - \\
\hline $\mathbf{T}$ & -0.12 & 0.14 & 0.09 & 0.06 & - & - & - \\
\hline RH & -0.05 & $0.48^{*}$ & $0.3^{* *}$ & $0.57^{*}$ & -0.37 & - & - \\
\hline AER & -0.19 & $-0.59^{*}$ & -0.21 & $-0.87^{*}$ & -0.16 & $-0.51^{*}$ & - \\
\hline
\end{tabular}

$$
{ }^{*} \mathrm{p}<0.01,{ }^{* *} \mathrm{p}<0.05
$$

The median TVOC concentration was higher after renovation $\left(575 \mu \mathrm{g} / \mathrm{m}^{3}\right)$ than before $\left(500 \mu \mathrm{g} / \mathrm{m}^{3}\right)$, but the difference was not significant (Figure 4b). The average TVOC concentrations in $80 \%$ of apartments before renovation and in $85 \%$ after renovation substantially exceeded the putative upper limit $\left(300 \mu \mathrm{g} / \mathrm{m}^{3}\right)$ recognized by the German Federal Environment Agency as a hygienically safe level [47]. The TVOC concentration exceeded $1000 \mu \mathrm{g} / \mathrm{m}^{3}$ in one apartment before renovation and in five apartments after renovation (Figure S5).

TVOC concentrations in this study were substantially higher than those reported in other studies [18, 31]. An increase in the average TVOC concentration was observed in 12 apartments (60\%) after renovation. Among these apartments, the ratio of TVOC concentration after and before renovation was between 1.01 and 8.41. Three apartments experienced more than 6-fold increase in TVOC levels. In these apartments, the occupants replaced old furniture or a carpet with new ones. This is in line with earlier studies where new materials, furniture and interior renovation were indicated to cause increased concentrations of volatile organic compounds $[48,49,50]$. We cannot therefore conclude that the performed energy renovation was solely responsible for the increased TVOC concentrations. However, the decreased air exchange rates likely contributed to the increase in TVOC levels in the apartments after renovation. 

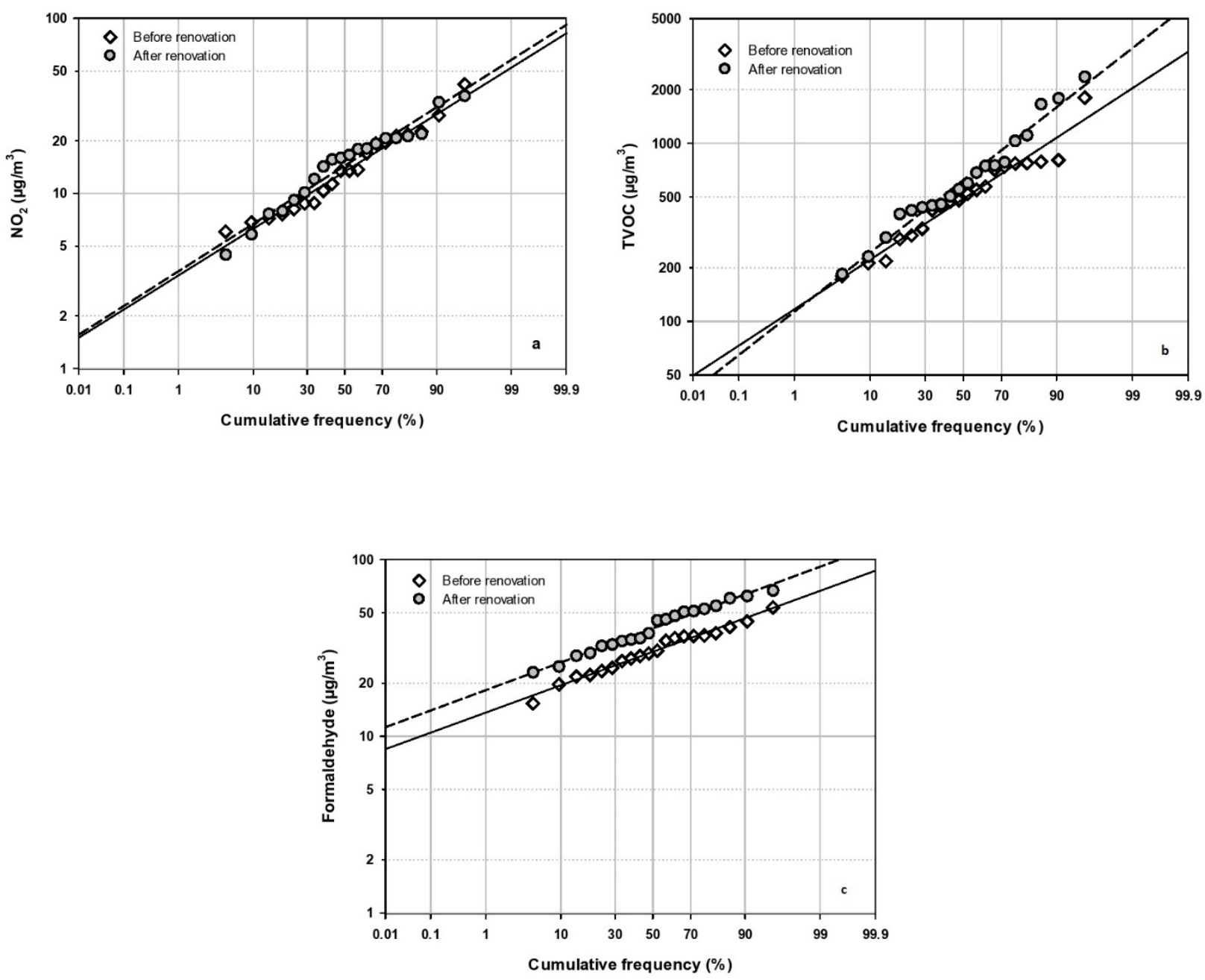

4 Figure 4. Cumulative frequency distribution of the $\mathrm{NO}_{2}$ (a), TVOC (b) and formaldehyde (c) concentrations 5 in Experiment II.

6 Table 4. Concentrations of the most abundant individual VOCs ( $\mu \mathrm{g} / \mathrm{m}^{3}$ as toluene equivalent).

\begin{tabular}{|l|c|c|c|c|c|c|c|c|}
\hline \multirow{2}{*}{ Compound } & \multicolumn{4}{|c|}{ Before Renovation (N=20) } & \multicolumn{4}{c|}{ After Renovation (N=20) } \\
\cline { 2 - 9 } & N>LOD & $\begin{array}{c}\text { Mean } \\
\text { (Std. Dev.) }\end{array}$ & $\begin{array}{c}\text { Geom. } \\
\text { Mean }\end{array}$ & Median & N>LOD & $\begin{array}{c}\text { Mean } \\
\text { (Std. Dev.) }\end{array}$ & $\begin{array}{c}\text { Geom. } \\
\text { Mean }\end{array}$ & Median \\
\hline Heptane & 20 & $\begin{array}{c}3.2 \\
(2.8)\end{array}$ & 2.5 & 2.6 & 18 & $\begin{array}{c}12.4 \\
(29.8)\end{array}$ & 6.8 & 5.5 \\
\hline Limonene & 20 & $\begin{array}{c}29.6 \\
(28.1)\end{array}$ & 19.8 & 19.2 & 20 & $\begin{array}{c}162.9 \\
(214.5)\end{array}$ & 85.2 & 88.9 \\
\hline a-pinene & 20 & $\begin{array}{c}4.2 \\
(4.4)\end{array}$ & 2.5 & 2.4 & 20 & $\begin{array}{c}7.2 \\
(11.7)\end{array}$ & 3.7 & 2.6 \\
\hline 3-carene & 15 & $\begin{array}{c}1.8 \\
(2.1)\end{array}$ & 3.8 & 1.0 & 19 & $\begin{array}{c}5.2 \\
(11)\end{array}$ & 2.6 & 1.7 \\
\hline Benzene* & 20 & $\begin{array}{c}3.9 \\
(2.8)\end{array}$ & 3.1 & 3.1 & 19 & $\begin{array}{c}2.0 \\
(0.7)\end{array}$ & 2.1 & 2.0 \\
\hline
\end{tabular}




\begin{tabular}{|l|c|c|c|c|c|c|c|c|}
\hline $\begin{array}{l}\text { Ethyl } \\
\text { Benzene }\end{array}$ & 20 & $\begin{array}{c}3.9 \\
(3)\end{array}$ & 3.2 & 3.1 & 20 & $\begin{array}{c}6.4 \\
(8)\end{array}$ & 4.4 & 4.5 \\
\hline Mp-Xylene & 20 & $\begin{array}{c}6.9 \\
(5.8)\end{array}$ & 5.2 & 5.3 & 20 & $\begin{array}{c}9.3 \\
(10.2)\end{array}$ & 6.9 & 6.3 \\
\hline Toluene & 20 & $\begin{array}{c}16.2 \\
(13.9)\end{array}$ & 12.1 & 11.1 & 20 & $\begin{array}{c}14.6 \\
(11.6)\end{array}$ & 11.9 & 11.6 \\
\hline Hexanal & 18 & $\begin{array}{c}7.5 \\
(8.8)\end{array}$ & 5.6 & 4.5 & 20 & $\begin{array}{c}10.0 \\
(6.5)\end{array}$ & 8.5 & 8.6 \\
\hline Nonanal & 19 & $\begin{array}{c}6.7 \\
(11.3)\end{array}$ & 6.4 & 6.1 & 20 & $\begin{array}{c}4.7 \\
(3.2)\end{array}$ & 3.7 & 3.9 \\
\hline $1-$ Butanol & 20 & $\begin{array}{c}12.0 \\
(5.8)\end{array}$ & 10.5 & 11.5 & 20 & $\begin{array}{c}12.7 \\
(6.4)\end{array}$ & 11.0 & 11.7 \\
\hline Isobutanol** & 20 & $\begin{array}{c}2.0 \\
(1.5)\end{array}$ & 1.6 & 1.5 & 18 & $\begin{array}{c}3.5 \\
(2.7)\end{array}$ & 3.1 & 2.8 \\
\hline $1-$ Pentanol & 17 & $\begin{array}{c}1.6 \\
(1.5)\end{array}$ & 1.2 & 1.3 & 20 & $\begin{array}{c}1.8 \\
(1.6)\end{array}$ & 1.4 & 1.2 \\
\hline $\begin{array}{l}\text { Hexanoic } \\
\text { acid* }\end{array}$ & 20 & $\begin{array}{c}5.0 \\
(4)\end{array}$ & 3.9 & 4.2 & 16 & $\begin{array}{c}0.8 \\
(0.5)\end{array}$ & 0.9 & 0.8 \\
\hline
\end{tabular}

${ }^{*} \mathrm{p}<0.01,{ }^{* *} \mathrm{p}<0.05$

2 In total 50 individual VOCs were identified. Table 4 summarizes the concentrations of the most abundant

3 individual VOCs. Significant difference between the two conditions of the building was observed in the

4 concentrations of limonene, benzene, isobutanol and hexanoic acid. The average concentration of benzene,

5 nonanal and hexanoic acid decreased after the renovation, while the concentrations of the other VOCs

6 increased. The presence of new sources and lower ventilation rates could have caused the increased

7 concentrations of indoor generated VOCs. However, different occupant activities during the two 1-week

8 measurement periods and consequently different indoor chemistry (e.g. terpene-ozone reactions) may have

9 also contributed to the observed differences. The levels measured in this study are comparable to those

10 obtained in Swedish apartments [30] and lower than reported for new buildings, as summarized by Derbez

11 et al. [19].

12 The concentrations of formaldehyde were significantly higher after renovation than before $(\mathrm{p}<0.05)$ (Figure

13 4c). The concentrations increased in $75 \%$ of the apartments after renovation, on average by $60 \%$ (Figure

14 S6). In the rest of the apartments they decreased only by about $10 \%$. Decreased AER after renovation of

15 the building may have significantly contributed to the increased formaldehyde concentrations in the

16 apartments. It is noteworthy, however, that insulation materials, including foam board insulation such as

17 the one used in the renovation process in the current study, could be major sources of formaldehyde [51].

18 Formaldehyde levels were in all apartments, both before and after renovation, below the 30-min average 
1 exposure limit of $100 \mathrm{mg} / \mathrm{m}^{3}$ recommended by the World Health Organization [45]. However, they were

2 above the chronic reference exposure level of $9 \mu \mathrm{g} / \mathrm{m}^{3}$, suggested by the California Office of Environmental

3 Health Hazards Assessment [52]. Our median concentrations were comparable to those observed in other

4 Western European countries [19, 49, 53, 54, 55, 56, 57] as well as Lithuania [22].

5 The significant negative correlation between AER and formaldehyde concentration (Table 3) reflects the

6 ability of ventilation to remove formaldehyde emitted indoors. Similar results were reported in a number

7 of earlier studies [31, 48, 51, 58]. Furthermore, significant positive correlation was found between relative

8 humidity and both TVOC and formaldehyde, which is consistent with earlier findings [51, 59].

9 Formaldehyde concentrations were positively correlated with temperatures, but the correlation was weak.

10 This may be explained by the relatively narrow range of indoor temperatures in the winter. In the stepwise

11 regression analysis AER, temperature and relative humidity were retained in the model as predictors of

12 formaldehyde concentration. These three variables explained $48 \%$ of the variation in the formaldehyde

13 concentrations (Table S3). AER and RH remained significant in the final model.

\section{$14 \quad 3.4$ Airing habits and perceived air quality}

15 The frequency of airing out in the bedroom was almost identical in the non-renovated and renovated

16 buildings in Experiment I. During daytime, the majority of occupants aired out "more than once a day"

17 (57\%) or “daily or almost daily” (41\%). The rest of the occupants aired out "at least once a week” (2\%).

18 During the night, about 45\% never aired out. The usual duration of airing during the day was similar in the

19 two building types ( $70 \%$ aired out less than $20 \mathrm{~min}$. at a time). The residents in the non-renovated buildings

20 indicated that during the night they air out over longer periods ( $60 \%$ longer than 45 min.) compared to the

21 occupants in the renovated dwellings ( $\sim 30 \%$ longer than 45 min.). These results are somewhat surprising,

22 given the fact that temperature was higher and indoor air quality poorer after renovation. However, $22 \%$ of

23 the occupants in the renovated buildings reported that they aired out more often since renovation than they

24 did before. No meaningful differences were observed in the self-reported airing habits before and after 
renovation in Experiment II. As expected, longer duration of airing out resulted in higher air exchange rates

2 and more acceptable indoor air quality (Figure S7).

3 The occupants found the indoor air quality in the bedroom and generally in the apartment more unpleasant

4 in the renovated buildings (Figure S8). They indicated lower acceptability of the indoor air quality in these

5 buildings $(\mathrm{p}<0.01)$ (Figure 5). Jurelionis and Seduikyte [23] found complaints about stuffy air and dry air

6 in Lithuanian multifamily dwellings more prevalent after renovation than before (64\% vs. 18\% for stuffy

7 air, 69\% and 29\% for dry air, respectively). The refurbishment included envelope insulation and new

8 windows; no changes were made to the ventilation.
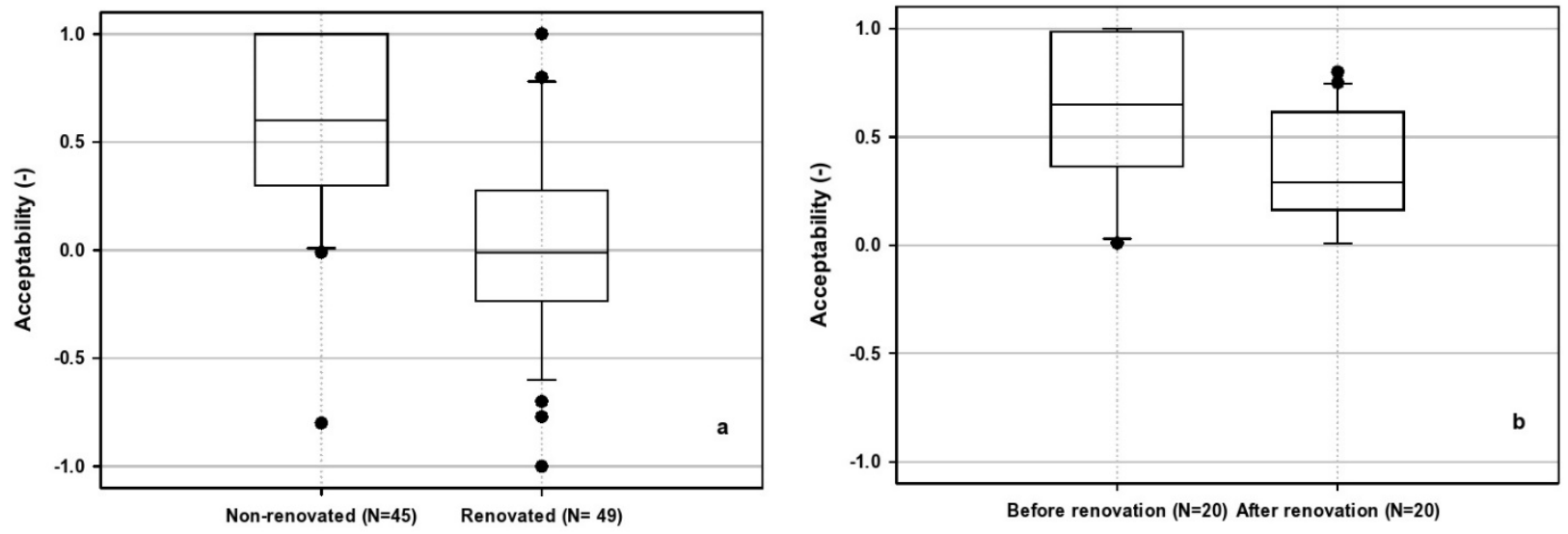

Figure 5. Acceptability of the indoor air in the apartments in Experiment I (a) and Experiment II (b). The bottom and the top of the boxes represent $25^{\text {th }}$ and $75^{\text {th }}$ percentiles and the band near the middle of the box is the median. The ends of the whiskers indicate $10^{\text {th }}$ and $90^{\text {th }}$ percentiles. The circles show the values below the $10^{\text {th }}$ and above the $90^{\text {th }}$ percentiles.

We observed a positive correlation between air exchange rate and acceptability of air quality ( $\mathrm{r}=0.79$, $\mathrm{p}<0.01$ ), and a negative correlation between formaldehyde concentrations and acceptability ( $\mathrm{r}=-0.53$, $\mathrm{p}<0.01$ ). The acceptability of indoor air quality was higher at lower TVOC concentrations, but the correlation was weak $(\mathrm{r}=-0.22, \mathrm{p}>0.05)$. Increased levels of VOCs caused by low ventilation rate may adversely affect perceived air quality. Wolkoff [60] reported that hexanal (linseed oil in building materials and human debris, e.g. skin oils), hexanoic acid (an oxidative degradation product from linseed oil and skin 
1 oils) and limonene (a common fragrance used in numerous consumer products) may be some of the most

2 important compounds influencing perceived air quality. Higher concentrations of hexanal and limonene

3 were observed after renovation (Experiment II).

4 Self-reported headache, itchy eyes, dry skin and fatigue were more prevalent after renovation than before

5 (Figure S9). In multivariate stepwise logistic regression analyses, building renovation was a significant

6 predictor of itchy eyes, along with sex and age of the occupants. However, the number of observations in

7 these analyses was too low to obtain conclusive results.

8 Numerous studies have reported reduced indoor exposures, fewer SBS symptoms and lower risk of 9 respiratory symptoms in new and renovated green buildings [16, 61, 62, 63]. These studies provide lessons 10 to be learned regarding the simultaneous improvement of indoor environmental quality, when planning 11 energy retrofitting of existing buildings. Protocols for selecting retrofits based on initial building conditions,

12 predicted energy use, indoor environmental quality changes and cost have the potential to improve building

13 performance and at the same time capitalize on the possible co-benefits of building retrofits [64]. The

14 development of such protocols, which would reflect regional needs and conditions, are warranted.

\section{4. Conclusions}

16 This study investigated the impact of relatively simple energy renovation measures on indoor air quality

17 and occupant comfort in multifamily residential buildings in Slovakia. Tightening the building envelope by

18 adding thermal insulation reduced infiltration through air leakage and thus the air exchange rates in the

19 apartments. Consequently, increased levels of formaldehyde and other volatile organic compounds were

20 observed. Relatively high concentrations of total volatile organic compounds (TVOC) were measured in a

21 large fraction of the apartments already before renovation. They were further elevated after renovation of

22 the building. The occupants perceived the indoor air quality as better before renovation. Building renovation

23 also resulted in slightly higher prevalence of some of the sick building syndrome symptoms. Energy

24 renovation without considering its potential impact on the indoor environment can adversely affect the 
1 indoor air quality. When old multifamily residential buildings in Central and Eastern Europe are upgraded

2 to be more airtight and energy efficient, the retrofitting effort should include measures to improve

3 ventilation in order to ensure acceptable and healthy indoor air quality. Installation of controlled natural

4 ventilation or mechanical ventilation systems is recommended. At the minimum, building occupants should

5 be encouraged to air out more often. These recommendations should be reflected in national building

6 renovation strategies and energy certification programs.

\section{5. Acknowledgements}

8 The study was supported by the Bjarne Saxhof Foundation, Denmark. We thank the participating families

9 for their cooperation. The authors also thank Gábor Bárdos and Imre Sánka for their assistance with the

10 measurements, Jakub Kolařík for technical advice and Dušan Ličina for his constructive comments on the

11 manuscript.

12

\section{References}

21 [1] F. Meijer, L. Itard, M. Sunikka, Comparing European residential building stocks, performance, 22 renovation and policy opportunities, Building Research and Information, 37 (2009) 533-551 
[2] Building Performance Institute Europe (BPIE), Europe's buildings under the microscope. A countryby-country review of the energy performance of buildings, BPIE (2011), ISBN: 9789491143014. URL: www.bpie.eu/wp-content/uploads/2015/10/HR_EU_B_under_microscope_study.pdf $\quad$ (Accessed 16 January 2017).

[3] Building Performance Institute Europe (BPIE), Renovation strategies of selected European countries. A status report on compliance with article 4 of the energy efficiency directive, BPIE (2014), ISBN: 9789491143113,URL: www.bpie.eu/uploads/lib/document/attachment/86/Renovation Strategies EU BPIE 2014.pdf (Accessed 16 January 2017).

[4] G.P. Panayiotou, S.A. Kalogirou, G.A. Florides, C.N. Maxoulis, A.M. Papadopoulos, M. Neophytou, P. Fokaides et al., The characteristics and the energy behavior of the residential building stock of Cyprus in view of Directive 2002/91/EC, Energy and Buildings 42 (2010) 2083-2089.

[5] J. Jokisalo, J. Kurnitski, J. Vinha, Building leakage, infiltration and energy performance analyses for Finish detached houses, Proceedings of CLIMA 2007:Well-being indoors (2007) Helsinki.

[6] W. Pan, Relationship between air-tightness and its influencing factors of post 2006 new-build dwellings in the UK, Building and Environment 45 (2010) 2387-2399.

[7] M.H. Sherman, W.R. Chan, Building Ventilation: The State of the Art, Part 4: Building airtightness: research and practice, Earthscan UK and USA (2006), ISBN-10:1-84407-130-8, ISBN-13:978-1-84407$130-2$.

[8] G. Villi, C. Peretti, S. Graci, M. De Carli, Building leakage analysis and infiltration modelling for an Italian multi-family building, Journal of Building Performance Simulation 6 (2013) 98-118.

[9] J. Korsgaard, Changes in indoor climate after tightening of apartments, Environment International 9 (1983) 97-101.

[10] L. Øie, H. Stymne, C.A. Boman, V. Hellstrand, The ventilation Rate of 344 Oslo Residences, Indoor Air 8 (1998) 190-196.

[11] W.J. Fisk, Health and productivity gains from better indoor environments and their relationship with building energy efficiency, Annual Review of Energy and the Environment 25 (2000) 537-566.

[12] A.P. Jones, Indoor air quality and health, Atmospheric Environment 33 (1999) 4535-4564.

[13] C.J. Weschler, H.C. Shields, The influence of ventilation on reactions among indoor pollutants: modelling and experimental observations, Indoor Air 10 (2000) 92-100.

[14] N. Klepeis, W.C. Nelson, W.R. Ott, J.P. Robinson, A.M. Tsang, P. Switzer, J.V. Behar et al., The National Human Activity Pattern Survey (NHAPS): a resource for assessing exposure to environmental pollutants, Journal of Exposure Analysis and Environmental Epidemiology 11 (2001) 231-252.

[15] P. Howden-Chapman, A. Matheson, J. Crane, H. Vriggers, M. Cunningham, T. Blakely, C. Cunningham et al., Effect of insulating existing houses on health inequality: cluster randomized study in the community, British Medical Journal 334 (2007) 460-464.

[16] F. Noris, G. Adamkiewicz, W.W. Delp, T. Hotchi, M. Russell, B. C. Singer, M. Spears et al., Indoor environmental quality benefits of apartment energy retrofits, Building and Environment 68 (2013) 170178. 
[17] L. Liu, P. Rohdin, B. Moshfegh, Evaluating indoor environment of a retrofitted multi-family building with improved energy performance in Sweden, Energy and Buildings 102 (2015) 32-44. [18] S. Langer, Bekö G., Bloom E., A. Widheden, L. Ekberg, Indoor air quality in passive and conventional new houses in Sweden, Building and Environment, vol. 93 (2015) 92-100. quality and comfort in seven newly built, energy efficient houses in France, Building and Environment 72 (2014) 173-187.

[20] M. Derbez, B. Berthineau, V. Cochet, C. Pingnon, J. Riberon, G. Wyart, C. Mandin et al., A 3-year follow-up of indoor air quality and comfort in two energy-efficient houses, Building and Environment 82 (2014) 288-299.

[21] R. Holopainen, S. Kalmi, E. Kahkonen, P. Pasanen, K. Reijula, Primary energy performance and perceived indoor environment quality in Finnish low-energy and conventional houses, Building and Environment 87 (2015) 92-101.

[22] L. Du, T. Prasauskas, V. Leivo, M, Turunen, M. Pekkonen, M. Kiviste, A. Aaltonen et al., Assessment

[25] MTCRDSR - Ministry of Transport Slovak Republic, Residential and Non-Residential Building Stock of indoor environmental quality

[23] A. Jurelionis, L. Seduikyte, Assessment of indoor climate conditions in multifamily buildings in Lithuania before and after renovation, Proceedings of the $2^{\text {nd }}$ International Conference Advanced Construction , Kaunas Univ. Technol., Kaunas, Lithuania (2010) 236-241.

[24] V. Kauneliene, T. Prasauskas, E. Krugly, I. Stasiulatiene, D. Ciuzas, L. Seduikyte, D. Martuzevicius, Indoor air quality in low energy residential buildings in Lithuania, Building and Environment 108 (2016) 63-72. Renovation Strategy (2014), Slovak Republic.

[26] ASTM. ASTM Standard D 6245-98 (2002), standard guide for using indoor carbon dioxide concentrations to evaluate indoor air quality and ventilation. American Society for Testing and Materials; 2002.

[27] G. Bekö, T. Lund, J. Toftum, G. Clausen, Ventilation rates in bedroom of 500 Danish children, Building and Environment 40 (2010) 2289-2295.

[28] ASTM standard D 6245-98, Standard guide for using indoor carbon dioxide concentrations to evaluate indoor air quality and ventilation, American Society for testing and Materials (2002).

[29] Y. Sun, Z. Wang, Y. Thang, J. Sundell, In China, Students in Crowded Dormitories with a Low Ventilation Rate More Common Colds: Evidence for Airbone Transmission, Plos One 11 (2011).

[30] P. Warkocki, Sensory pollution sources in buildings, Indoor Air 14 (2004) 82-91.

[31] S. Langer, G. Bekö, Indoor air quality in the Swedish housing stock and its dependence on building characteristics, Building and Environment 69 (2013) 44-54.

[32] M. Ferm, H. Rodhe, Measurements of air concentrations of $\mathrm{SO}_{2}, \mathrm{NO}_{2}$ and $\mathrm{NH}_{3}$ at rural and remote sites in Asia, Journal of Atmospheric Chemistry 27 (1997) 17-29. 
[33] ISO 16000-4, Indoor air - part 4: Determination of formaldehyde - diffusive sampling method,

2 Geneva: International Organization of Standardization (2004).

3 [34] ISO 16017-2, Indoor, ambient and workplace air e sampling and analysis of volatile organic 4 compounds by sorbent tube/thermal desorption/capillary gas chromatography - Part 2: Diffusive sampling,

5 Geneva: International Organization of Standardization (2003).

[35] ISO 7730, Ergonomics of the thermal environment -- Analytical determination and interpretation of thermal comfort using calculation of the PMV and PPD indices and local thermal comfort criteria (2005).

[36] T. Psomas, P. Heiselberg, K. Duer, E. Bjorn, Overheating risk barriers to energy renovations of single family houses: Multicriteria analysis and assessment, Energy and Buildings 117 (2016) 138-148.

[37] M. Kotol, C. Rode, G. Clausen, T. R. Nielsen, Indoor environment in bedrooms in 79 Greenlandic households, Building and Environment 81 (2014) 29-36.

[38] T. Kalamees, Indoor climate conditions and ventilation performance in Estonian lightweight detached houses, Indoor and Built Environment 15 (2006) 555-569.

[39] M. Kotol, Survey of occupants behaviour, enery use and indoor air quality in Greenlandic dwellings, 5th International Building Physics Conference (2012), Kyoto, Japan.

[40] L. Liu, B.P. Rohdin, B. Moshfegh, Evaluating indoor environment of a retrofitted multi-family building with improved energy performance in Sweden, Energy and Buildings 102 (2015) 32-44.

[41] H. Pustayova, Evaluation of energy performance and thermal comfort of dwellings in the process of refurbishment, Doctoral thesis (2013), Slovak University of Technology in Bratislava, Slovakia.

[42] G. Bekö., J. Toftum, G. Clausen, Modeling ventilation rates in bedrooms based on building characteristics and occupant behaviour, Building and Environment 46 (2011) 2230-2237.

[43] R. Routsalainen, R. Rönneberg, J. Säteri, A. Majanen, O. Seppänen, J.J.K. Jaakola, Indoor climate and the performance of ventilation in Finnish residences, Indoor Air 2 (1992) 137-145.

[44] C. Dimitroulopoulou, Ventilation in European dwellings: A review, Building and Environment 47 (2012) 109-125.

[45] World Health Organization (WHO), WHO Guidelines for indoor air quality: selected pollutants (2010), ISBN 978-92-890-0213-4.

[46] A. Kousa, C. Monn, T. Rotko, S. Alm, L. Oglesby, M.J. Jantunen, Personal exposure to $\mathrm{NO}_{2}$ in the EXPOLIS-study: relation to residential indoor, outdoor and work-place concentration in Basel, Helsinki and Prague, Atmospheric Environment 35 (2001) 3405-3412.

[47] B. Seifert, Regulating indoor air. Proceedings of the $5^{\text {th }}$ International Conference of Indoor Air Quality and Climate 5 (1990) 35-49, Toronto/Ottawa.

[48] J. S. Park, K. Ikeda, Variations of formaldehyde and VOC levels during three years in new and older homes. Indoor Air Indoor Air 16 (2006) 129-135.

[49] H. Järnström, K. Saarela, P. Kalliokoski, A.L. Pasanen, Reference values for indoor air pollutant concentrations in new, residential buildings in Finland, Atmospheric Environment 40 (2006) 7178-7191. 
[50] S.K. Brown, Volatile organic pollutants in new and established buildings in Melbourne, Australia, Indoor Air 12 (2002) 55-63.

3 [51] T. Salthammer, S. Mentese, R. Marutzky, Formaldehyde in the Indoor Environment, Chemical 4 Reviews 110 (2010) 2536-2572.

5 [52] Office of Environmental Health Hazard Assessment (OEHHA), Air toxics hot spots program. Risk 6 assessment guidelines. Guidance Manual for Preparation of Health Risk Assessments, OEHHA, California 7 Environmental Protection Agency (2015), URL: http://oehha.ca.gov/air/general-info/oehha-acute-8-hour8 and-chronic-reference-exposure-level-rel-summary [Accessed 20.11.16].

9 [53] J. Jurvelin, M. Vartianinen, M. Jantunen, P. Pasanen, Personal exposure levels and microenvironmental 10 concentrations of formaldehyde and acetaldehyde in the Helsinki metropolitan area, Finland, Journal of the 11 Air Waste Manage Association 51 (2001) 17-24.

12 [54] G.J. Raw, S.K.D. Coward, V.M. Brown, D.R. Crump, Exposure to air pollutants in English homes, 13 Exposure Analysis and Environmental Epidemiology 14 (2004) 85-94.

[55] P. Gustafsson, L. Barregård, R. Lindahl, G. Sällsten, Formaldehyde levels in Sweden: personal exposure, indoor, and outdoor concentrations, Exposure Analysis and Environmental Epidemiology 15 (2005) 252-260.

[56] C. Marchand, S.L. Calve, P. Mirabel, N. Glasser, A. Casset, N. Schneider, F. de Blay, Concentrations and determinants of gaseous aldehydes in 162 homes in Strasbourg (France), Atmospheric Environment 42 (2008) 505-516.

[57] B. Kolarik, L. Gunnarsen, A.Lagadottir, L.W. Funch, Concentrations of formaldehyde in new Danish residential buildings in relation to WHO recommendations and CEN requirements, Indoor and Built Environment 21 (2012) 552-561.

[58] Y. Maruo, T. Yamada, J. Nakamura, K. Izumi, M. Uchiyama, Formaldehyde measurements in residential indoor air using a developed sensor element in the Kanto area of Japan, Indoor Air 20 (2010) 486-493.

[59] S. Parthasarathy , R.L. Maddalena, M.L. Russel, M.G. Apte, Effect of temperature and humidity on formaldehyde emissions in temporary housing units, Journal of the Air and Waste Management 28 Association 6 (2011) 689-695.

[60] P. Wolkoff, Indoor air pollutants in office environments: Assessment of comfort, health, and performance, International Journal of Hygiene and Environmental Health 215 (2013) 371-39.

[61] M.D. Colton, J. G. Laurent., P. MacNaughton, J. Kane, M. Bennett-Fripp, J. D. Spengler, G. Adamkiewicz, Health Benefits of Green Public Housing: Associations With Asthma Morbidity and Building-Related Symptoms, American Journal of Public Health 105 (2015) 2482-2489.

[62] M.D. Colton, P. MacNaughton, J. Vallariono, J. Kane, M. Benett-Fripp, J.D. Spengler, G. Science and Technology 48 (2014) 7833-7841.

37 [63] J. Breysse, D.E. Jacobs, W. Weber, S. Dixon, C. Kawecki, S. Aceti, J. Lopez, Health outcomes and green renovation of affordable housing, Public Health Reports 126 (2011) 64-75. 
1 [64] F. Noris, W.W. Delp, K. Vermeer, G. Adamkiewicz, B.C. Singer, W.J. Fisk, Protocol for maximizing 2 energy savings and indoor environmental quality improvements when retrofitting apartments, Energy and 3 Buildings 61 (2013) 378-386. 